\title{
Abreu, Jorge Phelipe Lira de Existir em bits: arquivos pessoais nato- -digitais e seus desafios à teoria arquivística
}

\author{
José Francisco Guelfi Campos*
}

São Paulo: Associação de Arquivistas de São Paulo, 2018. 198p. (Thesis, 4).

Fruto da dissertação orientada por Aline Lopes de Lacerda e Luciana Heymann, defendida junto ao Programa de Pós-Graduação em Gestão de Documentos e Arquivos da UniRio, Existir em bits: arquivos pessoais nato-digitais e seus desafios à teoria arquivística, recém-editado pela Associação de Arquivistas de São Paulo, marca, de certa forma, a entrada de Jorge Phelipe Lira de Abreu na bibliografia brasileira sobre arquivos pessoais. Não se trata, convém notar, de estreia propriamente dita, tendo em vista que o autor vem publicando artigos em periódicos especializados e capítulos em coletâneas e anais de eventos realizados no país e no exterior.

Existir em bits, como anuncia seu subtítulo, é um livro sobre desafios, e um de seus vários méritos reside em sua originalidade. Num cenário teórico em que sequer a condição "arquivística" dos conjuntos de documentos acumulados por indivíduos é matéria de consenso, antecipa um horizonte ainda pouco vislumbrado pelos profissionais e estudiosos que se dedicam aos arquivos pessoais: o tratamento de documentos produzidos e acumulados em meio digital. Sem fugir ao jargão da metodologia da pesquisa no campo das Ciências Sociais Aplicadas, o autor define seu trabalho como estudo de natureza exploratória e qualitativa. Nenhum desses atributos, contudo, é capaz de traduzir a verdadeira essência da obra, cuja relevância emerge justamente de seu caráter empírico. Da articulação entre teoria e prática, Jorge Abreu soube extrair, oportunamente, as questões que dão corpo às suas reflexões.

\footnotetext{
* Universidade Federal de Minas Gerais (UFMG), Escola de Ciência da Informação, Departamento de Teoria e Gestão da Informação. Belo Horizonte, MG, Brasil. jfgcampos@eci.ufmg.br <https://orcid. org/0000-0002-9071-6082>
} 
De saída, o autor procura examinar o lugar ocupado pelos arquivos pessoais no processo de consolidação da teoria arquivística. Não se trata, é bem verdade, de empreitada fácil, dada a multiplicidade de vozes que vem povoando a literatura especializada. As peculiaridades desses arquivos - que parecem colocar em xeque os princípios consagrados da arquivística - têm dado margem, sobretudo nos últimos anos, a todo tipo de especulações, muitas das quais resultantes da apropriação inadvertida (e tardia) de ideias que despontaram na esteira da chamada virada linguística. Contemplando de maneira ponderada os diferentes pontos de vista, Abreu logrou compor um quadro que, embora não seja exaustivo, ilustra, a partir de referências atualizadas, as divergências a respeito da natureza dos arquivos acumulados por pessoas.

Os dilemas de ordem teórica e prática em torno do tratamento dos arquivos pessoais, que não são poucos, ganham outros contornos quando entram em cena os documentos nato-digitais, e os problemas relativos ao reconhecimento da proveniência, à identificação da autoria dos documentos, à presunção da autenticidade e à manutenção da organicidade dos arquivos revestem nova dimensão. Foi o que percebeu o autor ao lidar com o arquivo do escritor, músico e artista plástico carioca Rodrigo de Souza Leão, cuja parcela doada ao Arquivo-Museu de Literatura Brasileira da Fundação Casa de Rui Barbosa é composta, quase que em sua totalidade, por documentos produzidos e armazenados em meio digital.

Para tratar dessas questões, Jorge Abreu buscou na Diplomática dita "contemporânea" os aportes que, de um lado, contribuem para compreender a natureza e a lógica de produção dos documentos digitais e, de outro, concorrem para fundamentar, em consonância com os princípios arquivísticos, os procedimentos executados no desenrolar do arranjo e da descrição dos arquivos. Ainda no plano do embasamento teórico, convém chamar a atenção para a incorporação de referências aos estudos de gestão de informações pessoais (do inglês, personal information management), que exploram os modos e as estratégias com que os indivíduos criam, armazenam, recuperam e usam as informações contidas em documentos, sites e contas de correio eletrônico. Eivados de orientação marcadamente comercial, esses estudos podem, como bem sugere o autor, contribuir para a compreensão da lógica de acumulação documental no âmbito da intimidade, embora suas fronteiras com a teoria arquivística e suas relações com o universo dos arquivos destinados à preservação permanente ainda não estejam bem definidas. 
O relato das etapas que constituíram o tratamento do arquivo de Rodrigo de Souza Leão, concentrado no terceiro capítulo do livro, merece destaque especial não apenas pelo rigor com que a experiência foi conduzida por Rosely Curi Rondinelli, arquivista do Arquivo-Museu de Literatura Brasileira da Fundação Casa de Rui Barbosa, e pelo autor, então bolsista do Programa de Incentivo à Produção do Conhecimento Técnico e Científico na Área da Cultura, mas, sobretudo, pelas questões que dela afloram.

Como preservar a integridade de documentos armazenados em mídias de transporte altamente vulneráveis? E mais, como contornar o ofuscamento do contexto de produção ocasionado pela alteração dos metadados quando da transferência dos documentos? Quais os desafios para identificar a autoria e a proveniência de itens originalmente criados em computadores e outros dispositivos de uso compartilhado? Não bastassem esses dilemas, a equipe de trabalho deparou com os vestígios da incorporação de documentos por parte do representante legal da família, encarregado de formalizar e executar a doação do arquivo, situação que impôs obstáculos para a identificação da proveniência e para o reconhecimento do estatuto probatório dos documentos em relação às atividades desempenhadas pelo titular do fundo. As medidas de preservação em longo prazo e o estabelecimento de condições para a promoção do acesso foram outros elementos que constituíram o desafio enfrentado por Jorge Abreu, para além das dificuldades tipicamente associadas ao arranjo e à descrição de arquivos de literatos.

Nesse cenário, sem dúvida instigante, em que tudo parece desconhecido, convém questionar em que medida a realidade digital transforma, de fato, a natureza dos arquivos e do quefazer arquivístico. É certo que os documentos nato-digitais impõem dilemas que incidem sobre a prática e exigem, dos profissionais e estudiosos, a apropriação de novas ferramentas e um esforço de reflexão cujos desdobramentos teóricos resultam na produção de conhecimento original. Porém, os problemas que se colocam oferecem oportunidade valiosa para reafirmar aquilo que os arquivos têm de sui generis: o caráter essencialmente instrumental, que os torna capazes de representar, de maneira inigualável, as atividades e a trajetória de seus titulares (Camargo, 2009, p.36).

De uma forma ou de outra, a arquivística continua sendo, na feliz expressão de Angelika Menne-Haritz (1998), a ciência dos contextos e relações. Nisso repousam tanto a sua identidade quanto a validade dos princípios que a orientam. Na inevitável convivência dos suportes tradicionais com o meio digital, como bem notou Heloísa Bellotto (2014), o princípio da proveniência, o 
contexto de produção e o princípio da organicidade adquirem importância redobrada para a manutenção da condição probatória que caracteriza os documentos de arquivo. A inquietação manifestada, anos atrás, por Bruno Delmas (1996, p.49) a respeito da condição dos documentos nato-digitais nunca foi tão atual: em que pese a disparidade dos suportes, "quanto à realidade da informação consignada, não é tudo semelhante?".

Embora não ostente conclusões definitivas, e nem é esse o seu propósito, a pesquisa de Jorge Abreu há de inspirar e orientar a prática dos profissionais que já enfrentam dificuldades para tratar de arquivos híbridos e que, antes do que se imagina, terão de lidar com conjuntos cada vez maiores de documentos armazenados em meio digital. Dá, também, um pontapé inicial promissor numa seara de discussões à qual, em face do incessante desenvolvimento tecnológico, novos problemas se somarão, alguns dos quais já perceptíveis (como a correspondência e o compartilhamento de documentos por meio de aplicativos de transmissão de mensagens instantâneas e o uso das redes sociais como dispositivo de armazenamento) e outros ainda insondáveis. Por seu ineditismo, pelas reflexões que motiva e pelo desafio que projeta, Existir em bits se afirma como marco auspicioso em nossa literatura sobre arquivos pessoais.

\section{REFERÊNCIAS}

BELLOTTO, Heloísa Liberalli. Pertinência e permanência dos princípios arquivísticos na era digital. In: Arquivo: estudos e reflexões. Belo Horizonte: Ed. UFMG, 2014. p.156-169.

CAMARGO, Ana Maria de A. Arquivos pessoais são arquivos. Revista do Arquivo Público Mineiro, Belo Horizonte, ano 45, n.2, p.26-39, dez. 2009.

DELMAS, Bruno. Manifeste pour une diplomatique contemporaine: des documents institutionnels à l'information organisée. La Gazette des Archives, Paris, n.172, p.49-70, 1996.

MENNE-HARITZ, Angelika. What can be achieved with archives? In: THE CONCEPT OF RECORD: report from the Second Stockholm Conference on Archival Science and the Concept of Record, 30-31 May 1996. Stockholm: Riksarkivet, 1998. p.11-24.

Resenha recebida em 17 de junho de 2018.

Aprovada em 19 de junho de 2018. 